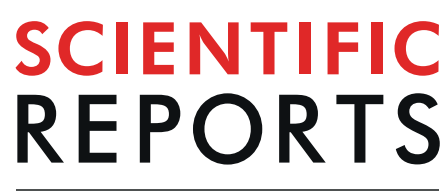

natureresearch

\title{
OPEN
}

Published online: 21 February 2020

\section{Author Correction: Integrating standardized whole genome sequence analysis with a global Mycobacterium tuberculosis antibiotic resistance knowledgebase}

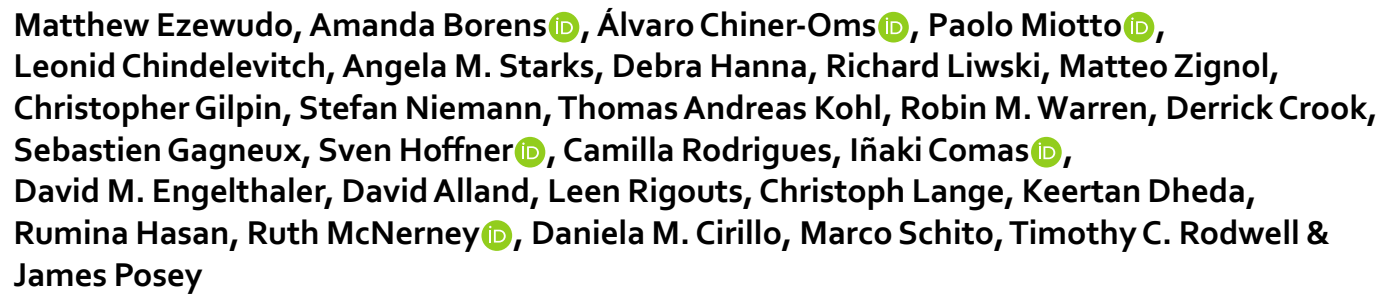
Leonid Chindelevitch, Angela M. Starks, Debra Hanna, Richard Liwski, Matteo Zignol, Christopher Gilpin, Stefan Niemann, Thomas Andreas Kohl, Robin M. Warren, Derrick Crook,

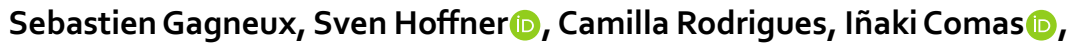
David M. Engelthaler, David Alland, Leen Rigouts, Christoph Lange, Keertan Dheda, Rumina Hasan, Ruth McNerney $\mathbb{D}$, Daniela M. Cirillo, Marco Schito, Timothy C. Rodwell \& James Posey

Correction to: Scientific Reports https://doi.org/10.1038/s41598-018-33731-1, published online 18 October 2018

The original version of this Article omitted an affiliation for Timothy C. Rodwell. The correct affiliations for Timothy C. Rodwell are listed below:

Department of Medicine, University of California, San Diego, CA, USA

The Foundation for Innovative New Diagnostics, Geneva, Switzerland.

This has now been corrected in the HTML and PDF versions of this Article.

(c) (1) Open Access This article is licensed under a Creative Commons Attribution 4.0 International License, which permits use, sharing, adaptation, distribution and reproduction in any medium or format, as long as you give appropriate credit to the original author(s) and the source, provide a link to the Creative Commons license, and indicate if changes were made. The images or other third party material in this article are included in the article's Creative Commons license, unless indicated otherwise in a credit line to the material. If material is not included in the article's Creative Commons license and your intended use is not permitted by statutory regulation or exceeds the permitted use, you will need to obtain permission directly from the copyright holder. To view a copy of this license, visit http://creativecommons.org/licenses/by/4.0/.

(C) The Author(s) 2020 